\title{
A Study on Child Labour as a Form of Child Abuse in Malaysia
}

\author{
Nik Ahmad Kamal Nik Mahmod, Marhanum Che Mohd Salleh, Ashgar Ali Muhammad, and Azizah \\ Mohd
}

\begin{abstract}
International Labour Organization (ILO) estimates that there are about 250 million economically active children worldwide. In Malaysia, although the Children and Young Persons Act (Employment) 1966 prohibits the children to be employed, previous studies proved that there are high rate of working children in certain states in Malaysia. It is believed that thousands of working children in Malaysia to be in an environment which is potentially harmful to their physical, mental, emotional, and social development. To identify the types and instances of child abuse for the working children, a study has been conducted to $\mathbf{4 5 4}$ working children in four states in Malaysia. Based on data analysis, it is found that more than half $(63 \%)$ of the working children have been emotionally abuse, $27 \%$ physically abused and at least $10 \%$ have been sexually abused. Majority of them are not happy with their current job and are regretful for not attending school. This represents their basic necessities to have proper education and they should not expose to work at this early age. This research contributes to increase the awareness of public and government to take care of the need of children basically on the issue of child abuse for working children.
\end{abstract}

Index Terms - Child labour, child abuse, working children, Malaysia.

\section{INTRODUCTION}

In any normal and decent environment, children should be able to rely and depend on adults especially their parents, close family and relatives for proper nurturing and guidance which they need in order to grow up. It is believed that many children have not received consistent and proper care from their parent that is essential for the optimum development of their lives. Besides the parent should be responsible to ensure the welfare of the children, it is the duty of government to ensure socio-economic rights for all citizens where children will be given adequate maintenance for their wellbeing. Basically the children should receive healthy food, nutrition, safe and potable water, accommodation, security, education, and medical treatment. If they are denied all these needs, it will affect them physically, mentally, and psychologically.

Manuscript received October 9, 2014; revised March 15, 2015. This work was supported in part by the Malaysian Ministry of Higher Education under Grant FRGS 13-047-0288.

Nik Ahmad Kamal Nik Mahmod, Ashgar Ali Ali Muhammad, and Azizah Mohd are with the Ahmad Ibrahim Kulliyyah of Laws, International Islamic University Malaysia (e-mail: nahmad@ iium.edu.my, ashgar@ iium.edu.my, azizahmohd@iium.edu.my).

Marhanum Che Mohd Salleh is with the Kulliyyah of Economics \& Management Sciences, International Islamic University, Malaysia (e-mail: marhanum@iium.edu.my).
Astonishingly, many children in developing countries do not have access to potable water, medical attention, sound education, food, good accommodation, and the necessary amenities. This would have a tremendous effect on children's growth and their functions to serve the countries in the future Thus, to survive, many children have to earn the little means that would enable them to cover their daily needs and to contribute to the parents and siblings. Child labour is one of the major and most rampant problems facing children in developing countries. Despite the fact that the law on child rights has been passed in many countries, there is lack of enforcement in some countries because of alleged inconsistencies with their religion and culture. In this context, children are forced to study and work at the same time as to supplement their families' income to improve their family's standard of living. If the working children are treated fairly, it is good to improve their skills and self confident, but in case the children who are denied necessary and basic rights or working under hazardous conditions which will affect their health, physical development and education, or engage in harmful employment; it is legally and rationally prohibited in the interest of the child.

This research focuses on the background of working children in Malaysia and investigates the issue of child abuse experienced by these children at the workplace. After introduction, it is followed by literature review on the contributing factors that made the children involves in employment. This is followed by methodology adopted in this research which is quantitative method, data analysis, results, and discussion. This research paper ends with conclusion and suggestion for future research.

\section{Child Labour in Malaysia}

International Labour Organization (ILO) estimates that there are about 250 million economically active children (individuals below 18 years old) worldwide. Sixty one percent or roughly 153 million of these workers are in Asia. Around half of the economically active children are working full time and $20-30 \%$, or about 30 to 46 million are in exploitative conditions or worst forms of child labor.

In Asia, many of these child labourers who are young as seven years old, are hidden. They work as household help, workers in farming and fishing industries, providers of sex services, workers in quarries, mines, brick kilns, construction sites, and increasingly in drug trade. A lot more in many Asian societies live in full public view as scavengers, street beggars, vendors, and workers in small scale or home-based industries. Since these types of work are considered 
"informal," regulation of the industries does not exist and monitoring the presence of children in the workplace is not commonly done.

There is no universally accepted definition of 'child labour'. Generally, it is taken to mean the employment of children under an age determined by law or custom, that is children start to work before they reach the minimum age for employment. They participate in a wide variety of economic activities in the production of goods and services to earn a living for themselves or for others. In order to enhance its response to effectively eliminate child labour, in 1992 the International Labour Organization's (ILO) created the International Programme on the Elimination of Child Labour (IPEC). ILO-IPEC had defined child labour as “... work situations where children are compelled to work on a regular basis to earn a living for themselves and their families, and as a result are disadvantaged educationally and socially..." In other words these children are forced to carry out activities that are normally regarded as adult responsibilities. The work that they do harms or exploits them in some ways physically, mentally, morally or by blocking access to education. Thus, child labour is work that keeps children from attending school.

Child labour not only violates a nation's minimum wage laws, but also threatens the children's physical, mental or emotional wellbeing. Child labour is generally regarded as exploitative although some social scientists point out that some kinds of work may be acceptable. In fact in Article 32 of the Convention on the Rights of the Child 1989, the United Nations stipulated that it is, ... the right of child to be protected from economic exploitation and from performing any work that is likely to be hazardous or to interfere in the child's education, or to be harmful to the child's health or physical, mental, emotional, spiritual, moral or social development.

In Malaysia, Section 1A(1) of the Children and Young Persons (Employment) Act 1966 defines a child as ....any person who has not completed his fourteenth year of age or of such age as the Yang di-Pertuan Agong (King) may by notification in the Gazette prescribe... "In Malaysia, under the Age of Majority Act 1966, the age of majority is set at 18 years, and there is no law totally banning child labour". When the Children and Young Persons (Employment) Act was passed in 1966, it repealed the Children and Young Persons Ordinance 1947, which had a minimum age of 8 years for working children. The current Act does not have a minimum age.

\section{Child's Rights}

There has been a growing attention regarding children's rights, particularly in the last 30 years or so. This growing attention has led to the United Nations Convention on the Rights of the Child (UNCRC) in 1989 to call for protection of children from economic exploitation and from work that threatens their health, education or development (Article 32 of the UNCRC). Generally, it is recognised that children have rights to education, to care from their parents, to rest and relaxation. All of which may be compromised due to the children's involvement with work. They are basically deprived of their childhood, their right to recreate and play and of their natural development. The Convention speaks of rights of children covering four broad areas namely the right to:

1) Survival, which includes adequate living standards and access to medical services;

2) Development, including education, access to information, leisure and cultural activities, to play, freedom of thoughts, conscience and religion;

3) Protection, from all forms of exploitation, abuse and cruelty, arbitrary separation from family and from abuse of the criminal justice system; and

4) Participation, including the freedom to express opinions and to be a part of a decision in matters affecting the young person's life.

Malaysia ratified the UNCRC in 1995. This means that the government has the responsibility to make sure that all Malaysian children has all the rights as stated in the Convention, except for the expressed reservations or as long as they do not contravene the Constitution, national laws and national policies of the government.

\section{REASONS OF WORKING CHILDREN}

In many countries of the world, including Malaysia, the phenomenon of child labour persists despite the existence and implementation of laws and regulations to reduce or even eliminate the problem. The Convention on the Rights of the Child clearly underscores the need to protect children from economic exploitation and from performing any work that is clearly to be hazardous, however child employment continues to prevail in many developing countries [1]. Although the exact figures of children working is not known, but in the year 2000, the ILO estimates that “... 246 million child workers aged 5 and 17 were involved in child labour, of which 171 million were involved in work that by its nature is hazardous to their safety, physical or mental health, and moral development. Moreover, some 8.4 million children were engaged in so-called 'unconditional' worst forms of child labour, which include forced and bonded labour, the use of children in armed conflict, trafficking in children and commercial sexual exploitation..." [2].

However, in the four-year period between 2000-2004, child labour was seen to have declined about $10 \%$ and then continue to decline by about three percent $(3 \%)$ in the four-year period 2004-2008 [2]. In many instances, children are preferred as workforce because they are easy to manipulate, intimidate, abuse and exploit due in part to their inexperience and relative immaturity. In Malaysia although the Children and Young Persons Act (Employment) Act 1966 does not encourage the employment of children, studies show that there are children in employment [3], [4]. However, similar with some other countries it is difficult to cite the number of children actually engaged in child labour in Malaysia. In fact very little is known about the actual magnitude, nature and distribution of child labour in the country. This is because little has been done to collect and analyse current relevant data regarding the incidence of child labour in the country. Also official data on child labour is very limited. 
Furthermore, the Act permits some exceptions such as children are allowed to do light work in family enterprises or as an approved apprentice, although they may not work for more than six (6) hours per day, or six (6) days per week or at night. In the Population Census of 1980 it was cited that the number of children between the ages of 10 to 14 years in the work force was 43,000 [11]. The number declined to 39,746 children in the 1991 Population Census [5].

There are many reasons why children work which depending on the culture of a society or country, family beliefs, socio-economic conditions among other reasons. There are also many types of child labour including domestic labour, agricultural labour, farm labour, and street workers (vendors, porters and shoeshine). However, their labour participation means that they are denied or deprived of their right to education, which is crucial to their future prospects, personal development and directly or indirectly to the development of a country. They are not attending school as they should or are not spending enough time on educational development. The notion that the children are being exploited and deprived of formal education is a cause for concern for many people. This is because education is regarded as crucial for the children's personal development and future. Also, these children are part of the country's future human capital and as such may have an impact on its future social and economic situations. Even when work does not prevent school attendance, it can have an adverse effect on the children's school performance. Not only those, these children are also deprived of their 'childhood' as they become 'premature adults'.

A study conducted by [6] in 2007-2008 at Sabah have found that the main reason that brought the children to the working space is because of financial needs of their family. This situation parallels with the finding from previous study by [7] where poverty has positive relationship with child labour. The other factors that influenced the child labour in Sabah found by [6]'s are because of their choice to exert selves' independence $(38.5 \%)$ and also by parent advice (7.7\%). In this context, some parents believed that the job experience gained by their children would later assist them in the future career, rather than spending time at schools. This is happen basically for the poor family whereby the children not performing well in school.

\section{Other Countries}

Respectively, the study of child labour in Bangladesh and India found that the patterns of involvement in economic activity by gender differ in the two countries. In Bangladesh, boys are much more likely to be involved in economic activity. Involvement in economic activity is highest, and the gender gap is largest, in rural areas. In India, by contrast, gender considerations appear to play a relatively minor role in household decisions concerning child labour. Girls' economic activity rate approaches that of boys, especially in rural areas.

Meanwhile, study conducted in Indonesia and Pakistan by [8] on the home-worker children have regards that children in this category have a higher probability of working and a lower probability of attending school than children which is not involve in any home-base activity. In addition, there is evidence of the feminisation of home-base from childhood, and female children have a double burden to carry. This is dramatic in Pakistan while little evidence is found in Indonesia. The regression results show that, together with other determinants, as age increases, children are more likely to work in home-base. In Pakistani urban slums the majority of children are working but in Indonesia they are in school. However, the pull factor of work and the push factor of unaffordable (and possibly poor-quality) schooling combine to induce drop out from school. It was noticed that home-base within the household reduces the fixed costs for children (and parents) of ending work outside the home, since it reduces the transportation costs, transaction costs, and allows for a higher divisibility of work "contracts" inside the household business. Further that that, the mother's education level and per capita income/expenditure or assets in the household were important determinants of the child's activity status. Finally, the hours that children work in Pakistan suggest that their ability to do school-related activities is likely to be impacted.

In addition, [9] have investigated to what extent the participation of child labour leads to lower school attendance and increased repetition and dropout rates, and whether child labour affects girls and boys differently. The data in their study was collected in MICS and DHS household surveys from 18 African countries. 60 percent of children aged 7 to 14 years in the sample are attending school and 38 percent are engaged in child labour. 20 percent of all children are combining school attendance and child labour. A regression analysis shows that household wealth and education of the mother are the most important determinants of school attendance. Children from wealthier households and children of mothers with a formal education are more likely to attend school. In the majority of the countries in the study, boys, urban residents, and children not engaged in labour also have an increased probability of school attendance.

\section{Methodology}

A research can be designed qualitatively, quantitatively, or with mixed qualitative-quantitative methodology. This present research is designed quantitatively where the data for the study is collected through a survey based on self-administered questionnaires. The questionnaires basically cover the research objectivesand gather demographic information of the respondents. All of the questionnaires are developed for this research based on literatures review.

The pilot study was conducted to test the questionnaires and measurement items for clarity and understanding. It is a necessary step in the data collection process to identify any problems with the research instrument, and to determine the content and face validity of the measures used in the questionnaires. In this process, a few experts in Law were involved as well as 30 working children in Selangor and Melaka. Parallel with the final sampling frame, the pilot study has involved working children below 17 years old. This is consistent with [10] view that the pilot sample should be typical and representative. Upon the successful completion the pilot test, the final survey was conducted. The 
respondents are 454 working children of 4 states in Malaysia. Data collected were analyzed using a Statistical Package for Social Sciences (SPSS) version 19.

\section{RESUltS}

\section{A. Background of Working Children}

As presented in Table I (see appendix), a total of 454 respondents (working children) have contributed in this research. It is observed that majority of the working children that participated in this research are males (60 percent). It could represent the actual number of working children which majority are male rather than female. In terms of age, most of the children were from the older group age, which is the age group between 15 and 17 years-old ( 81 percent) and the rest belong to 10-15 years old age group (19 percent). However, only one of them was from the youngest group (5-10 years old).

In addition, most of the children are Muslims (72 percent) and Malays (62 percent). It is followed by Chinese (14 percent), other races (14 percent), and the least were Indian (10 percent). Among the current job that involved by the children are in restaurant, cyber café, business, car wash, night market, sales, and many others as indicated in Table 1. Basically, most of them have working as shop assistant (84 children), followed by restaurant worker ( 74 children), have own business (48 children), and car wash worker (38 children). It is observed that their family's education (mother and father) mostly having secondary school as their highest education. Moreover, majority of their parents still married (82 percent) while the rest (18 percent) either were divorced or passed away. Therefore, more than half of the children still leave with both of their parents (77 percent) while only 18 percent either stay with their mother or father and 5 percent leaving with others. Details on the background of the children are presented in the Table 1 (see the appendix).

\section{B. Types of Child Abuse}

Base on descriptive analysis, the research found that at least 108 working children have experienced physical abuse. From this figure, more than half of them (69.5 percent) have been pushed and beaten while working and nearly one-third have been manhandled ( 23 percent). Meanwhile, the other physical abuse are thrown out (3.7 percent children suffered), beaten and pushed ( 2.8 percent children suffered), and beaten and manhandled ( 0.9 percent children suffered). Table II presents details on the number of working children that have been experienced physical abuse together with the valid percentage.

TABLE II: PHYSICAL ABUSE

\begin{tabular}{|c|c|c|}
\hline Types of physical abuse & Frequency & Percentage \\
\hline Beaten & 33 & 30.6 \\
\hline Thrown Out & 4 & 3.7 \\
\hline Pushed & 42 & 38.9 \\
\hline Manhandled & 25 & 23.1 \\
\hline Beaten and Pushed & 3 & 2.8 \\
\hline Beaten and Manhandled & 1 & 0.9 \\
\hline Total & 108 & 100.0 \\
\hline
\end{tabular}

In addition, the research also asked the working children whether they have been emotionally abused while working. Unfortunately, more than half of the working children (54 percent) have been mistreated emotionally which includes threaten, despise, and insulted. Accordingly, majority of the children reported that they always been insulted by their employers while working (215 children). And the rest of them were either been threaten (10 children) and despise (12 children). Table III below presents details on this result.

TABLE III: EMOTIONAL ABUSE

\begin{tabular}{|l|c|c|}
\hline $\begin{array}{c}\text { Types of emotional } \\
\text { abuse }\end{array}$ & Frequency & Percentage \\
\hline Threaten & 10 & 4.08 \\
\hline Despise & 12 & 4.90 \\
\hline Insulted & 215 & 87.80 \\
\hline Threaten and Insulted & 6 & 2.45 \\
\hline Threaten and Despise & 1 & 0.41 \\
\hline Despise and Insulted & 1 & 0.41 \\
\hline Total & $\mathbf{2 4 5}$ & $\mathbf{1 0 0 . 0}$ \\
\hline
\end{tabular}

The other issue faced by the working children was in terms of food and treatment. In this regards, the research found that at least 67 children have experienced this issues. In particular, more than half ( 56.72 percent) reported that they have been denied treatment by the employers when something happen during working. Details on this result were presented in Table IV below.

TABLE IV: NEGLECTED

\begin{tabular}{|c|c|c|}
\hline Types of abuse & Frequency & Percentage \\
\hline Denied food & 29 & 43.28 \\
\hline Denied treatment & 38 & 56.72 \\
\hline Total & $\mathbf{6 7}$ & $\mathbf{1 0 0 . 0}$ \\
\hline
\end{tabular}

Finally, the research also investigates whether there are an issue of sexual abuse on the working children in Malaysia. In this context, 38 of the working children have experienced either raped, sexual threat, or molested. From this number, most of them were faced sexual threat in their work place (60.53 percent). Meanwhile, 14 children have been molested and there was one case where the child was raped while working. Table $\mathrm{V}$ below presents details on this result.

TABLE V: SEXUAL ABUSE

\begin{tabular}{|l|c|c|}
\hline $\begin{array}{c}\text { Types of emotional } \\
\text { abuse }\end{array}$ & Frequency & Percentage \\
\hline Raped & 1 & 2.63 \\
\hline Sexual threat & 23 & 60.53 \\
\hline Molested & 14 & 36.84 \\
\hline \multicolumn{1}{|c|}{ Total } & $\mathbf{3 8}$ & $\mathbf{1 0 0 . 0}$ \\
\hline
\end{tabular}

\section{FINDINGS AND DISCUSSION}

The aims of the current research is to investigate the background of working children in Malaysia and also to examine the issue of child abuse in this country whether it is in critical stage that need some action to be taken. Base on past studies, the background of children that basically relate to their gender, parents' educational level, and income have much influenced them to involve into working environment. For example, [11] find that it is the father's education that has the greatest impact using data from Brazil, whereas [12] find 
that it is the mother's education that has the greatest effect using data from rural India. Interestingly, both [11] and [12] find that the father's education has a larger effect on the labour force participation of sons than of daughters, indicating a gender aspect to the decision to send children to school or to work. Similarly, this research found that the educational level of the majority of the parents' of working children were in secondary level and this basically represent low family income which require the children to work as to support the family members.

Additionally, child labor was primarily regarded as a demand-driven phenomenon, in recent decades much attention has focused on supply factors such as demography, poverty and family-income choices [13]. In poor countries, children often form part of collective family strategies for income generation [14]. Family or social crises may force children to drop out of school in order to generate income, and compulsory schooling may push children into part-time work to cover school costs. Previous studies acknowledge that increases in family wealth, and a diminution in poverty levels, will result in households electing to withdraw their children from the labor market (Amin et al., 2004; Salmon, 2005; Bar \& Basu, 2009). This research however did not found any influence of the family problem made the children to work as the results indicate that most of their family still married and they are staying with both of them.

Interestingly, this research looks into the issue of child abuse for working children. Base on data analysis, there are three types of child abuse that have been experienced by working children in Malaysia. It's including physical, emotional, and sexual abuse. Base on Fig. 1 below, majority of the children were emotionally abused (whereby majority of them reported that they were always been insulted by their employers. This should not be happen for working children as they still not reach matured level and need full guidance from their employers to do the assigned job. If the employers realised their responsibility towards enhancing the capability of the working children, there would bright future for the company and also the children themselves. Consequently, this may lead to a positive perception towards the phenomenon of working children in a general.

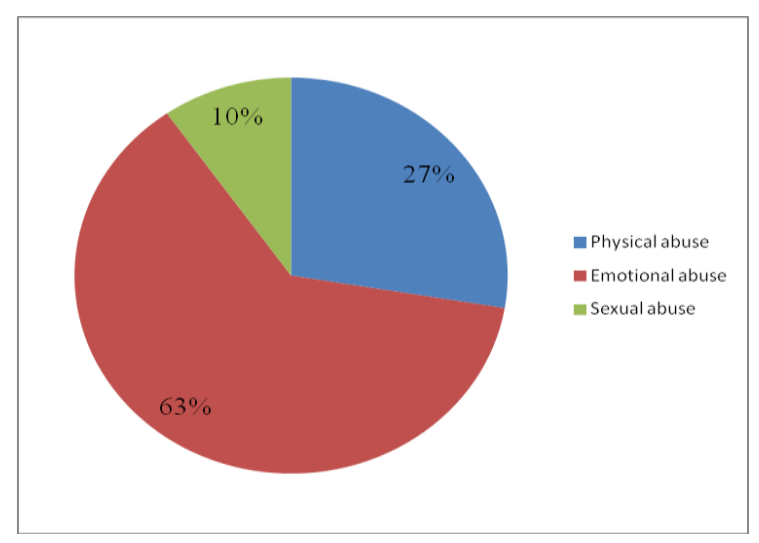

Fig. 1. Types of child abuseconclusion and suggestion for future research.

Overall, this research basically investigates the background of the working children in Malaysia and focuses on the issues of child abuse in workplace. Simple descriptive analyses have been conducted to achieve the research objectives. Based on the results, it is realised that the working children still been abused physically, mentally, and sexually. In this regards, severe rules and enforcement should be done to the employers who have hired children in their company. To achieve this target, full commitment from the public and government is needed so as to ensure the working children are under proper treatment by their employer.

In terms of future research, it is suggested to explore the condition of working children at the poor country where it is believed that they are more expose to the issue of child abuse either physical, emotional, or sexual abuse. As this research only limit to Malaysia context, the issue of child abuse can be regarded as controllable. However, there are countries where the children are fully utilised and treated unfairly by the irresponsible employers. Future research can be conducted to explore these countries by using case study methodology.

\section{APPENDIX}

Background of working children:

\begin{tabular}{|c|c|c|c|}
\hline \multicolumn{2}{|c|}{ Demographic Information } & \multirow{2}{*}{$\begin{array}{l}\text { Frequency } \\
270\end{array}$} & \multirow{2}{*}{$\begin{array}{c}\begin{array}{c}\text { Percent } \\
(\%)\end{array} \\
59.5\end{array}$} \\
\hline Gender & Male & & \\
\hline & Female & 184 & 40.5 \\
\hline & Total & 454 & 100.0 \\
\hline \multirow[t]{4}{*}{ Age Group } & $5-10$ years & 1 & 0.2 \\
\hline & $10-15$ years & 86 & 18.9 \\
\hline & $15-17$ years & 367 & 80.8 \\
\hline & Total & 454 & 100.0 \\
\hline \multirow[t]{5}{*}{ Race } & Malay & 281 & 61.9 \\
\hline & Indian & 44 & 9.7 \\
\hline & Chinese & 64 & 14.1 \\
\hline & Others & 65 & 14.3 \\
\hline & Total & 454 & 100.0 \\
\hline \multirow[t]{6}{*}{ Religion } & Islam & 325 & 71.6 \\
\hline & Hindu & 26 & 5.7 \\
\hline & Buddhist & 45 & 9.9 \\
\hline & Christian & 53 & 11.7 \\
\hline & Others & 5 & 1.0 \\
\hline & Total & 454 & 100.0 \\
\hline \multicolumn{2}{|c|}{ Demographic Information } & Frequency & $\begin{array}{l}\text { Percent } \\
(\%)\end{array}$ \\
\hline Mothers' & No formal education & 59 & 13.0 \\
\hline \multirow[t]{5}{*}{ Education } & Primary school & 112 & 24.7 \\
\hline & Secondary school & 207 & 45.6 \\
\hline & University & 72 & 15.9 \\
\hline & Others & 4 & 0.8 \\
\hline & Total & 454 & 100.0 \\
\hline Fathers' & No formal education & 34 & 7.5 \\
\hline \multirow[t]{5}{*}{ Education } & Primary school & 110 & 24.2 \\
\hline & Secondary school & 221 & 48.7 \\
\hline & University & 82 & 18.1 \\
\hline & Others & 7 & 1.5 \\
\hline & Total & 454 & 100.0 \\
\hline \multirow{5}{*}{$\begin{array}{l}\text { Parents' marital } \\
\text { status }\end{array}$} & Married & 372 & 81.9 \\
\hline & Divorced & 60 & 13.2 \\
\hline & Pass away & 20 & 4.4 \\
\hline & Unknown & 2 & 0.4 \\
\hline & Total & 454 & 100.0 \\
\hline \multirow[t]{5}{*}{ Guardian } & Mother \& Father & 349 & 76.9 \\
\hline & Father & 23 & 5.1 \\
\hline & Mother & 59 & 13.0 \\
\hline & Others & 23 & 5.1 \\
\hline & Total & 454 & 100.0 \\
\hline \multirow[t]{3}{*}{ Occupation } & Boutique & 4 & 0.9 \\
\hline & Bus conductor & 10 & 2.2 \\
\hline & Business & 45 & 9.9 \\
\hline
\end{tabular}




\begin{tabular}{|c|c|c|}
\hline Cafeteria & 2 & 0.4 \\
\hline Car wash & 38 & 8.4 \\
\hline Cashier & 28 & 6.17 \\
\hline Cyber cafe & 23 & 5.1 \\
\hline Chef & 4 & 0.9 \\
\hline Cleaner & 4 & 0.9 \\
\hline Clerk & 6 & 1.3 \\
\hline Construction & 4 & 0.9 \\
\hline Technician & 2 & 0.4 \\
\hline Factory worker & 5 & 1.1 \\
\hline Farmer & 2 & 0.4 \\
\hline Fast-food & 17 & 3.7 \\
\hline Labour-force & 12 & 2.6 \\
\hline Hotel & 3 & 0.7 \\
\hline Mechanic & 18 & 4.0 \\
\hline Night market & 11 & 2.4 \\
\hline Petrol station & 4 & 0.9 \\
\hline Restaurant & 74 & 16.3 \\
\hline Sales \& promotion & 24 & 5.3 \\
\hline Saloon & 4 & 0.9 \\
\hline Shop assistant & 84 & 18.5 \\
\hline Teacher & 8 & 1.8 \\
\hline Others & 20 & 4.4 \\
\hline Total & 454 & 100.0 \\
\hline
\end{tabular}

\section{REFERENCES}

[1] A. Admassie, "Child labour and schooling in the context of a subsistence rural economy: Can they be compatible?," International Journal of Educational Development, vol. 23, pp. 167-185, 2003.

[2] I. L. Organization. (2010). [Online]. Available: http://www.ilo.org/global/standards/lang--en/index.htm

[3] K. Jomo, Child Labour in Malaysia, Kuala Lumpur: University of Malaya, 1992.

[4] M. George, "Children in employment in peninsular Malaysia," in Child Labour in Malaysia, Kuala Lumpur: University of Malaya, 1992, pp. $1-75$.

[5] D. O. Statistic. (1995). Global Built AssetWealth Index 2013. [Online] Available: http://www.statistics.gov.my/main/main.php

[6] A. A. Rahimah and I. Suriati, "Working children and knowledge of right to education: A study of child labour in Sabah, Malaysia," Asian Social Science, vol. 9, no. 8, pp. 23-33, 2013.

[7] K. K. Mehra, "Children at work: how many and where?" World of Work, vol. 15, pp. 8-9, 1996.

[8] M. Biggeri, R. Libanora, S. Mariani, and L. Menchini, "Children conceptualizing their capabilities: results of a survey conducted during the first children's world congress on child labour," Journal of Human Development, vol. 7, no. 1, 2006.

[9] E. D. Gibbons, F. Huebler, and E. Loaiza, Child Labour, Education, and the Principle of Non-Discrimination, New York: United Nations Children's Fund (UNICEF), 2005.

[10] W. G. Zikmund, Business Research Methods, South-Western: Thomson, 2003

[11] P. A. S. A. Emerson, "Birth order, child labor, and school attendance in Brazil," World Development, vol. 36, no. 9, pp. 1647-1664, 2008.

[12] T. Kurosaki and H. Khan, "Human capital, productivity, and stratification in rural Pakistan," Review of Development Economics, vol. 10, no. 1, pp. 116-134, 2006.

[13] M. Manacorda, "Child labor and the labor supply of other household member: Evidence from 1920 America," American Economic Review, vol. 96 , no. $1788-1801$
[14] S. E. S. J. Jennings and A. L. Aitken, "Reproducing life and labor: Global processes and working children in Tijuana, Mexico," Childhood, vol. 13, no. 3, pp. 365-387, 2006.

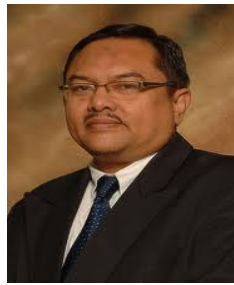

Nik Ahmad Kamal Nik Mahmod obtained his bachelor of laws at University of Malaya, master of law at King's College, University of London, England, diploma in Shariah law and practice at International Islamic University, and doctor of philosophy at University of Aberdeen, Scotland. He has published articles at International and Local journals which include Asian Law Institute (ASLI) Law Journal, and Macquarie Journal of International and Comparative Environmental Law, Kashmir University Law Journal and IIUM Law Journal, He has received emerald literati network award for outstanding paper 2009 for "Biosafety protocol SPS agreement and export and import control of LMOs/GMOs" in the Journal of International Trade Law and Policy.

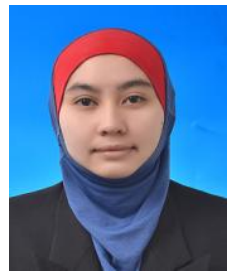

Marhanum Che Mohd Salleh obtained her bachelor degree from University of Malaya in year 2008, specialization in Shariah and Management. She did her $\mathrm{MSc}$ degree in finance and pursue her $\mathrm{PhD}$ in Islamic Banking at International Islamic University Malaysia. Her area of expertise includes Islamic marketing, Islamic finance, banking, and Takaful. She has published her works Australian Journal of Basic and Applied Sciences, Journal of Islamic Finance and Business Research, Journal of Islamic Finance, and International Journal of at-Thaqafah.

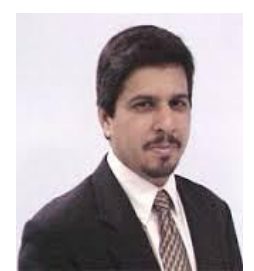

Ashgar Ali Muhammad obtained LL.B (Hons) and MCL from International Islamic University Malaysia (IIUM), LL.M (Hons) (New Zealand), and Ph.D (business law), advocate and solicitor (University Malaya). His area of specialisation is employment law and sub-specialisation are civil Ligitation and Shariah court civil procedure. He has published articles at International and Local journals including Malaysian Current Law Journal, International Journal of Humanities an Social Science, Journal of Applied Sciences Research, International Journal of Sustainable Development, and Malayan Law Journal.

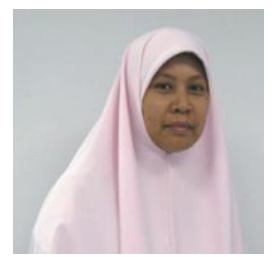

Azizah Mohd studied at International Islamic University Malaysia since 1983 and graduated with LLB, LLB(S), MCL and PhD in 2005. Her area of expertise including Islamic family law, child rights, child protection. She is the author for a book 'Protection and adoption of abandoned children in Malaysia: A comparative overview with Islamic law'. Among the journals that became her medium of publication: Australian Journal of Basic Applied Sciences (AJBAS), Journal of Islamic Law Review (JILR), Asia Pacific Journal of Social Work and Development, and OIDA International Journal of Sustainable Development. 